\title{
RUANG LINGKUP KEWENANGAN PERADILAN AGAMA DALAM MENGADILI SENGKETA EKONOMI SYARIAH
}

\author{
Diana Rahmi \\ Fakultas Syariah dan Ekonomi Islam IAIN Antasari, Jl. Jenderal Ahmad Yani Km 4,5 Banjarmasin \\ e-mail:diana.rahmi@rocketmail.com
}

\begin{abstract}
After the implementation of the Act No. 3 year 2006, the dispute of Islamic Economic is absolutely included as the domain of the Islamic Court's competence, and would be entirely resolved by this court as well. However, some regulations recently lead to reduce this competence belongs to the Islamic Court by making this court not the only institution to resolve the dispute of Islamic Economic. In fact, the domain of the Islamic Court that is extended to settle all the Islamic Economic disputes, is also reduced by a clause that potentially indicate to resolve the

dispute outside from the Islamic Court (as stated in the contract), and also by a conflict settled on the of Islamic arbitration.

Abstrak : Sejak lahirnya Undang-Undang No. 3 Tahun 2006, sengketa ekonomi Syariah masuk dalam lingkup kewenangan Absolut Peradilan Agama. Namun peraturan perundang-undangan yang lahir belakangan, telah mereduksi kewenangan dimaksud. Peradilan Agama bukanlah satu-satunya lembaga yang berwenang menangani sengketa tersebut. Ruang lingkup kewenangan Peradilan Agama dalam mengadili sengketa ekonomi Syariah adalah melingkupi semua sengketa ekonomi Syariah bidang Hukum Perdata dengan subyek hukum Islam dan non Islam, namun tidak melingkupi klausul yang memperjanjikan penyelesaian sengketa selain Peradilan Agama (sesuai isi akad) dan juga tidak melingkupi hal-hal terkait putusan arbitrase Syariah.
\end{abstract}

Kata Kunci: Kewenangan absolut, peradilan agama, sengketa ekonomi syariah

\section{Pendahuluan}

Dalam negara hukum Republik Indonesia yang berdasarkan Pancasila dan UUD 1945, kedudukan badan Peradilan Agama adalah merupakan salah satu pelaku dan penyelenggara kekuasaan kehakiman. Ia mempunyai kedudukan yang sejajar dengan peradilan-peradilan lainnya dalam menegakan hukum. Sebagaimana badan peradilan lainnya, kekuasaan kehakiman di lingkungan Peradilan Agama juga berpuncak pada Mahkamah Agung sebagai pengadilan negara tertinggi. Hal ini tercermin dalam Pasal 3 ayat 2 Undang-Undang Nomor 7 Tahun 1989. Peradilan Agama, dalam penyelesaian perkaranya maka pelaksanaannya tak dapat dilepaskan sama sekali daripada hukum agama yaitu Islam. Walaupun demikian, Undang-Undang Nomor 3 tahun 2006 Pasal 49 telah memberikan batasan jenis perkara apa saja yang menjadi kewenangan absolutnya.

Peradilan Agama sebagai perwujudan Peradilan Islam di Indonesia secara garis besar wilayah pengkajiannya tercermin dalam rumusan pengertiannya, yang secara rinci meliputi: pertama, kekuasaan negara, yaitu kekuasaan kehakiman yang bebas dari campur tangan kekuasaan negara lainnya dan dari pihak luar; kedua, pengadilan dalam lingkungan Peradilan Agama, meliputi hirarki, susunan, pimpinan, hakim, panitera, dan unsur lain dalam susunan organisasi pengadilan; ketiga, prosedur berperkara di pengadilan, yang mencakup jenis perkara, hukum prosedural, dan produkproduknya; keempat, perkara-perkara di bidang perkawinan, kewarisan, wasiat, hibah, perwakafan, zakat, infaq, dan shadaqah serta ekonomi syariah. Ia mencakup variasi dan sebarannya dalam berbagai badan peradilan; kelima, orangorang yang beragama Islam sebagai pihak yang berperkara, atau para pencari keadilan; keenam, hukum Islam sebagai hukum substansial yang dijadikan rujukan; ketujuh, penegakan hukum dan keadilan.

Bila dikaji secara lebih dalam, perwujudan Peradilan Agama di Indonesia dapat dilihat dari beberapa sudut pandang. Pertama, secara filosofis peradilan dibentuk dan dikembangkan untuk menegakan hukum dan keadilan. Hukum 
yang ditegakan adalah hukum Allah yang telah disistematisasi oleh manusia. Sedangkan keadilan yang ditegakan adalah keadilan Allah, sebagaimana tercermin di dalam Kepala Putusan Pengadilan "Bismillaabirrahmaanirrabiim" dan Demi Keadilan Berdasarkan Ketubanan Yang Maba Esa". $\underline{\text { Kedua, }}$ secara yuridis hukum Islam (di bidang perkawinan, kewarisan, wasiat, hibah, wakaf, zakat, infaq, shadaqah dan ekonomi syariah) berlaku di pengadilan dalam lingkungan Peradilan Agama. Ketiga, secara historis Peradilan Agama merupakan salah satu mata rantai peradilan Islam yang berkesinambungan sejak masa Rasulullah SAW. Keempat, secara sosiologis Peradilan Agama didukung dan dikembangkan oleh dan di dalam masyarakat Islam. ${ }^{1}$

Daniel S. Lev menggambarkan bahwa pertumbuhan dan perkembangan Peradilan Agama yang kelihatannya ganjil, tidak hanya mampu bertahan hidup tetapi dalam berbagai hal mengalami perkembangan yang semakin kuat. Sedangkan di negara-negara Islam lainnya, pranata-pranata hukum keagamaan banyak yang dihapus dan dibatasi. ${ }^{2}$

Eksistensi Peradilan Agama dalam sistem tata hukum di Indonesia, menemukan momentunnya yaitu sejak disahkan dan diundangkannya UU Nomor 14 Tahun 1970. Kemudian menyusul UU Nomor 1 Tahun 1974 dan PP Nomor 9 tahun 1975, PP Nomor 28 Tahun 1977, UU Nomor 7 Tahun 1989, dan Inpres Nomor 1 Tahun 1991 tentang KHI. Peraturan perundangundangan tersebut menuntut berbagai konsekuensi, antara lain pembentukan PA diseluruh wilayah kabupaten/kotamadya dan PTA di seluruh wilayah propinsi ; peningkatan kualitas PA dan PTA diseluruh wilayah Indonesia; penambahan jumlah hakim dan panitera pengganti; pengangkatan jurusita; peningkatan kualitas hakim dan panitera; peningkatan kualitas administrasi peradilan; dan penambahan serta peningkatan sarana dan prasarana yang mendukungnya. ${ }^{3}$

1 Cik Hasan Bisri, Peradilan Agama Di Indonesia, (Jakarta: Raja Grapindo Persada, 1996), hlm. 23, 24 $\& 33$.

2 Zaini Ahmad Noeh (Trans). Daniel S. Lev, Peradilan Agama di Indonesia, ( Jakarta: Intermasa, 1980), hlm. ix.

3 Cik Hasan Bisri. Loc. Cit.
Kehadiran Undang-Undang Nomor 7 tahun 1989 membawa dampak positif dan dapat mengakhiri perlakuan tidak wajar terhadap Peradilan Agama sebagai peradilan yang sudah ada semenjak tahun 1882.4 Menurut Bustanul Arifin sebagaimana dikutif oleh Cik Hasan Bisri, Undang-Undang Nomor 7 Tahun 1989 adalah lompatan raksasa. Dari segi perundang-undangan dia adalah lompatan 100 tahun dan dari segi hukum substantif dia adalah lompatan 100 windu. Itulah mungkin yang menyebabkan RUUPA begitu ramai ditanggapi. Intisari masyarakat Pancasila adalah keluarga, dan karena itu adanya Peradilan Agama yang merupakan peradilan keluarga (family Court) bagi orang-orang Islam Indonesia amat menguntungkan, karena keadilan dan kepastian hukum yang diberikan Peradilan Agama akan mewujudkan kehidupan keluarga yang tenang dan damai. Putusanputusan Peradilan Agama yang bertali ke langit dan berakar kebawah (masyarakat) akan mendatangkan kesejukan bagi masyarakat. ${ }^{5}$ Akan tetapi walaupun demikian, rentang waktu lahirnya Undang-Undang Nomor 7 tahun 1989 sangatlah panjang, yaitu 29 tahun kemudian setelah adanya pengaturan dalam UU Nomor 14 tahun 1970. Walaupun dalam Pasal 10 UU Nomor 14 Tahun 1970, Peradilan Agama berada pada urutan kedua setelah Peradilan Umum, namun yang lahir lebih dahulu adalah UndangUndang tentang Peradilan Umum dan PTUN yaitu tahun 1986. Padahal persiapan draf RUU Peradilan Agama telah dipersiapkan sekitar sepuluh tahun sebelumnya. Akhirnya Peradilan Agama jauh tertinggal beberapa tahun. Suatu hal yang aneh terjadi bagi lembaga hukum Islam, terabaikan di tengah-tengah umatnya yang mayoritas. ${ }^{6}$

Berangkat dari perkembangan terakhir Peradilan Agama pada masa reformasi ini, seiring dengan perubahan terhadap penyelenggaraan kekuasaan kehakiman dan dalam rangka memperkuat prinsip kekuasaan kehakiman yang merdeka, sesuai dengan tuntutan reformasi di bidang hukum, maka sebagai konsekuensi dari perubahan peraturan perundang-undangan yang

\footnotetext{
4 Ibid. hlm. 137-138

5 Ibid. hlm. 243.

6 Abdul Halim, Peradilan Agama dalam Politik. Hukum di Indonesia. Dari Otoriter Konservatif Menuju Konfigurasi Demokratis-Responsif, (Jakarta: RajaGrafindo Persada, 2000), hlm. 141.
} 
ada, Peradilan Agama sebagaimana diatur dalam Undang-Undang Nomor 7 tahun 1989 juga mengalami perubahan. Hal ini dikarenakan Undang-Undang Nomor 7 Tahun 1989 dalam konteks kekinian sudah tidak sesuai lagi dengan perkembangan kebutuhan hukum masyarakat dan kehidupan ketatanegaraan menurut UndangUndang Dasar Negara Republik Indonesia Tahun 1945.

Perubahan terhadap Undang-Undang Nomor 7 Tahun 1989 oleh Undang-Undang No 3 Tahun 2006 dan Undang-Undang No. 50 Tahun 2009, pada dasarnya adalah untuk menyesuaikan terhadap Undang-Undang Nomor 48 tahun 2009 tentang Kekuasaan Kehakiman dan UndangUndang Nomor 3 Tahun 2009 tentang perubahan kedua atas Undang-Undang Nomor 14 Tahun 1985 tentang Mahkamah Agung. Dengan dilakukan perubahan berarti pula telah diletakkan dasar kebijakan secara menyeluruh bahwa segala urusan mengenai Peradilan Agama, baik menyangkut teknis yudisial maupun non yustisial yaitu organisasi, administrasi dan finansial di bawah kekuasaan Mahkamah Agung. Disamping itu perubahan Undang-Undang No 7 tahun 1989, akan semakin memantapkan kedudukan dan eksistensi Peradilan Agama itu sendiri dalam sistem tata hukum di Indonesia.

Salah satu perubahan yang juga dianggap signifikan terhadap Undang-Undang No. 7 Tahun 1989 adalah Pasal 49 menyangkut kewenangan absolut Peradilan Agama. Sebagaimana tertuang dalam Undang-Undang No. 3 Tahun 2006 Pasal 49 menjelaskan bahwa "Pengadilan Agama bertugas dan berwenang memeriksa, memutus, dan menyelesaikan perkara-perkara di tingkat pertama antara orangorang yang beragama Islam di bidang perkawinan, waris, wasiat, hibah, wakaf, zakat, infaq, shadaqah; dan ekonomi syari'ah".

Dalam perubahan tersebut kewenangan Peradilan Agama diperluas. Perluasan tersebut antara lain meliputi zakat, infaq, objek sengketa hak milik yang subjek hukumnya antara orang yang beragama Islam dan ekonomi syari'ah. Yang digarisbawahi dari kewenangan baru Peradilan Agama adalah ekonomi Syariah. Sebelumnya bidang ekonomi baik Syariah maupun Konvensional adalah merupakan kewenangan Peradilan Umum, sehingga dengan berlakunya perubahan ini sebagian kewenangan absolut dari Peradilan Umum menjadi kewenangan absolut Peradilan Agama.

Berbeda dengan penganturan bidang perkawinan atau lainnya yang lebih rinci sehingga dapat memudahkan hakim menguji perkara yang diajukan kepadanya termasuk dalam batasan kewenangannya atau tidak. Maka pengaturan bidang ekonomi Syariah, tidaklah serinci sebagaimana dimaksud diatas. Padahal ekonomi Syariah termasuk masalah yang komplek dan tidak mudah serta berkembang sangat pesat, dapat membuka ruang serta memungkinkan siapa saja bisa terlibat di dalamnya.

Hal ini tentu menimbulkan sedikit kekhawatiran akan terulangnya trauma yang pernah dirasakan oleh Peradilan Agama terkait kewenangan absolutnya. Apalagi jika ditelusuri beberapa perundang-undangan yang lahir belakangan, menegaskan bahwa Peradilan Agama bukanlah satu-satu lembaga yang berwenang menangani persoalan ekonomi Syariah. Misalnya terkait ketentuan Pasal 55 UndangUndang Perbankan Syariah tentang penyelesaian sengketa. Hal inilah yang membuat Penulis tertarik mengkaji lebih jauh terkait jangkauan kewenangan Peradilan Agama dalam mengadili sengketa ekonomi Syariah. Dengan diketahuinya jangkauan kewenangan dimaksud akan berfungsi sebagai rel untuk menertibkan jalur batas kewenangan yurisdiksi mengadili antar peradilan.

\section{Dinamika Historis Perkembangan Regulasi Dan Lembaga Ekonomi Berbasis Syariah Di Indonesia}

Secara substantif eksistensi ekonomi Syariah bukanlah hal baru dalam dunia Islam. Ini dikarenakan keberadaannya sudah ada sejak agama Islam hadir di bumi ini. Al Quran dan Hadis dipenuhi dengan hukum-hukum dan pengarahan kebijakan ekonomi, yang berfungsi sebagai kerangka atas kebijakan dan langkah yang ingin direalisasikan. Konsep dasar yang ditawarkan Al Quran dan Hadis akan mengatur gerak langkah pelaku ekonomi dalam menjalankan kegiatan ekonominya.

Perkembangan Hukum Ekonomi Syariah di Indonesia diawali dengan munculnya Perbankan Syariah dan karenanya tidak perlu menggunakan istilah ekonomi Islam sebagaimana dipergunakan 
banyak Negara, tetapi ekonomi Syariah sebagai terminologi yang bersifat khas Indonesia. ${ }^{7}$

Sebelum munculnya gagasan tentang perlunya didirikan Bank Syariah di Indonesia, para cendekia muslim baik yang ada di organisasi keagamaan maupun kalangan perbankan dan perorangan telah melakukan pengkajian tentang bunga bank dan riba. KH. Mansur ketua pengurus Muhammadiyah pada tahun 1937 telah mempunyai keinginan untuk berdirinya Bank Syariah. Namun kehendak ini gagal karena dianggap SARA pada saat itu dan dikhawatirkan akan mengganggu stabilitas nasional.

Majelis Tarjih Muhammadiyah pada Muktanar di Sidoardjo Jawa Timur tahun 1968 memutuskan bahwa bunga yang diberikan oleh bank-bank Negara kepada nasabah demikian pula sebaliknya, hukumnya syubhat artinya belum jelas halal dan haramnya. Karenanya, sesuai dengan petunjuk hadis kita harus berhatihati menghadapi masalah-masalah yang masih syubhat itu. ${ }^{8}$ Guna menjaga prinsip kehati-hatian bermuamalah dengan bank yang menerapkan bunga tersebut, KH Azhar Basjir, MA Ketua Majelis Tarjih Muhammadiyah waktu itu memberikan rambu-rambu bahwa menentukan hukumnya bunga bank harus dipertimbangkan besar kecilnya bunga atau keuntungan siapa yang memperoleh dan untuk siapa keuntungan itu dimanfaatkan. ${ }^{9}$

Bahsul masa'il Nahdhatul Ulama (NU) telah menfatwakan bahwa bunga bank itu halal. Namun kendati demikian, dalam wawancara dengan wartawan surat kabar harian Media Indonesia edisi 27 Juli 1990 Ketua Umum Pengurus Besar NU tetap bercita-cita untuk berdirinya bank yang beroperasi sesuai dengan prinsip syariat Islam di Indonesia. ${ }^{10}$

Sehingga terlepas pendapat yang setuju dan tidak terhadap bunga bank, yang pasti kenyataan menunjukkan bahwa umat Islam pada umumnya

7 Abdurrahman, Penyelesaian Sengketa Ekonomi Syariah di Indonesia, (Banjarmasin: Makalah Orasi Ilmiah disampaikan pada Pembukaan Kuliah Fakultas Syariah IAIN Antasari, 30 Agustus 2010), hlm. 3.

8 Warkum Sumitro, Asas-Asas Perbankan Islam dan LembagaLembaga terkait ( $B A M U I$ dan Takaful) di Indonesia, (Jakarta: RajaGrafindo Persada, 1997), hlm. 71.

9 Muhammad Daud Ali, Sistem Ekonomi Islam, Zakat dan Wakaf, (Jakarta: Universitas Indonesia Press, 1988), hlm. 13.

10 Warkum Sumitro, Op.Cit, hlm. 72. merasa ragu-ragu. Di satu pihak sesuai dengan tuntutan perkembangan kebutuhan ekonomi mereka harus berhubungan dengan bank. Dilain pihak perasaan takut akan melanggar aturan agama dikarenakan ada unsur ribanya. Hal ini tentu tidak bisa dibiarkan karena keadaan ini akan mengganggu peran kaum muslimin untuk turut serta dalam membangun ekonomi bangsa dan negaranya yang tercinta ini.

Gagasan berdirinya Bank Syariah di Indonesia lebih konkret pada saat lokakarya "Bunga Bank dan Perbankan" pada tanggal 18-20 Agustus 1990. Ide tersebut ditindaklanjuti dalam Munas IV Majelis Ulama Indonesia (MUI) di Hotel Syahid tanggal 22-25 Agustus 1990.

Kemudian MUI membentuk suatu Tim Steering Commite yang diketuai oleh DR. Ir. Amin Aziz. Tim ini bertugas mempersiapkan segala sesuatu terkait dengan berdirinya Bank Syariah di Indonesia. Guna membantu kelancaran tugastugas Tim MUI dibentuklah Tim Hukum Ikatan Cedekiawan Muslim Indonesia (ICMI) di bawah ketua Drs. Karnaen Perwaatmadja, MPA. Tim ini bertugas untuk mempersiapkan segala sesuatu menyangkut aspek hukum dari Bank Syariah, karena baik dalam proses berdirinya maupun pada saat beroperasinya, Bank Syariah selalu berhubungan dengan aspek hukum. ${ }^{11}$

Selain mempersiapkan proses berdirinya Bank Syariah, baik segi administrasi maupun pendekatan-pendekatan dan konsolidasi dengan pihak-pihak terkait, Tim MUI juga mempersiapkan aspek sumber daya manusianya, hingga persoalan dananya dengan melobi pengusaha-pengusaha muslim untuk menjadi pemegang saham pendiri. Tim MUI dapat melaksanakan tugasnya dengan baik, terbukti dalam kurun waktu 1 tahun sejak ide berdirinya Bank Syariah serta dukungan dari umat Islam dan berbagai pihak sangat kuat, maka setelah semua persyaratan terpenuhi tanggal 1 November 1991 dilakukan penandatanganan akte pendirian Bank Muamalat Indonesia (yang selanjutnya disingkat BMI). Bertempat di Sahid Jaya Hotel dengan akte Notaris Yudo Paripurna, SH. Dengan izin Menteri Kehakiman No.C.2.2413.HT.01.01. Kemudian dengan izin prinsip Surat Menteri Keuangan Republik Indonesia No. 1223/MK.013/1991 tanggal 5 November 1991, Izin usaha Keputusan Menteri

11 Ibid. hlm. 73 
Keuangan Republik Indonesia No. 430/KMK :013/1992, tanggal 24 April 1992 dan pada tanggal 1 Mei 1992 BMI bisa memulai operasi untuk melayani kebutuhan masyarakat melalui jasa-jasanya. ${ }^{12}$ Jadi, walaupun BMI didirikan tahun 1991 tetapi baru beroperasi pada tanggal 1 Mei 1992, menjadi Bank Umum pertama yang beroperasi berdasarkan prinsip-prinsip Syariah. Kelahiran BMI menjadi tonggak awal tumbuh dan berkembanganya sistem keuangan dan bisnis Syariah di Indonesia.

Guna mengakomodir perkembangan yang ada terutama terkait masalah perbankan, tanggal 25 Maret 1992 ditetapkan Undang-Undang No. 7 Tahun 1992 (LN 1992 No. 23) tentang Perbankan yang mencabut dan menggantikan Undang-Undang No. 14 Tahun 1967 tentang Pokok-Pokok Perbankan, yang dalam pertimbangannya menggariskan bahwa perbankan yang berasaskan demokrasi ekonomi dengan fungsi utamanya sebagai penghimpun dan penyalur dana masyarakat, memiliki peranan yang strategis untuk menunjang pelaksanaan pembangunan nasional, dalam rangka meningkatkan pemerataan pembangunan dan hasil-hasilnya, pertumbuhan ekonomi, dan stabillitas nasional, kearah peningkatan taraf hidup rakyat banyak. Perkembangan perekonomian nasional maupun internasional yang senantiasa bergerak cepat disertai dengan tantangan-tantangan yang semakin luas, harus selalu diikuti secara tanggap oleh perbankan nasional dalam menjalankan fungsi dan tanggung jawabnya kepada masyarakat. Undang-Undang No. 14 Tahun 1967 tentang pokok-pokok dan beberapa undang-undang di bidang perbankan lainnya yang berlaku sampai saat ini, sudah tidak dapat mengikuti perkembangan perekonomian nasional maunpun internasional, sehingga kemudian diterbitkan Undang-Undang tentang Perbankan yang baru.

Pasal 5 Ayat (1) undang-undang ini menggariskan bahwa menurut jenisnya bank terdiri dari Bank Umum dan Bank Perkreditan Rakyat. Berdasarkan undang-undang ini dimulailah langkah untuk menngakomodasikan dan memberi landasan hukum terhadap bank-bank Syariah yang sudah terbentuk mulai berjalan.

Undang-Undang No. 7 Tahun1992 tentang Perbankan, tidak secara eksplisit menyebutkan adanya apa yang disebut "Bank Syariah". Hanya ada dua yang dapat dijadikan dasar, yaitu Pasal 6 huruf $(\mathrm{m})$ yang berkenaan dengan lingkup perbankan umum dan Pasal 13 huruf (e ) yang berkenaan dengan salah satu lingkup kegiatan Bank Perkreditan Rakyat dengan isi yang sama menyebutkan "Menyediakan pembiayaan bagi nasabah berdasarkan prinsip bagi hasil sesuai ketentuan yang ditetapkan dalam peraturan pemerintah.

Dengan demikian istilah yang digunakan dalam undang-undang ini "Bank Berdasarkan Prinsip Bagi Hasil". Pasal 6 huruf (m) dan Pasal 13 huruf (e) belum banyak memberikan pengaturan lanjutan terkait apa yang dimaksud dengan istilah prinsip bagi hasil itu sendiri, landasan hukum operasionalnya, dan kegiatan usaha apa saja yang dapat dioperasionalkan dan diimplementasikan oleh bank tersebut. Tetapi perlu digarisbawahi disini, lahirnya UndangUndang Perbankan ini merupakan langkah maju dari perjuangan semua pihak. Realitas yang demikian, memberikan harapan besar yang menumbuhkan optimisme bagi kita semua guna terus berupaya mengembangkan ekonomi Syariah di Indonesia.

Selanjutnya pada tanggal 30 Oktober 1992 ditetapkan Peraturan Pemerintah No. 72 Tahun 1992 (LN 1992 No. 119) tentang Bank Berdasarkan Prinsip Bagi Hasil. Pasal 1 Ayat (1) menentukan bahwa bank berdasarkan prinsip bagi hasil adalah Bank Umum atau Bank Perkreditan Rakyat yang melakukan kegiatan usaha semata-mata berdasarkan prinsip bagi hasil. Adapun Penjelasan Pasal yang bersangkutan (TLN No. 3505) menyebutkan bahwa yang dimaksud dengan prinsip dari bagi hasil dalam peraturan pemerintah ini adalah "prinsip muamalat berdasarkan Syariat" dalam melakukan kegiatan usaha bank. Dari perkataan "prinsip muamalat berdasarkan Syariat", ini kemudian berubah menjadi berdasarkan "prinsip Syariah" dan secara singkat disebut "Bank Syariah" atau "Perbankan Syariah". Jadi secara formal istilah Bank Syariah atau bank berdasarkan prinsip Syariah mulai diperkenalkan dalam Peraturan Pemerintah No. 72 Tahun 1992.13

Pasal 6 Ayat (2) Peraturan Pemerintah No. 72 Tahun 1992 menjelaskan bahwa "Bank Umum atau Bank Perkreditan Rakyat yang

13 Abdurrahman, Op.Cit. hlm. 6. 
kegiatan usahanya tidak berdasarkan prinsip bagi hasil tidak diperkenankan melakukan kegiatan usaha yang berdasarkan prinsip bagi hasil". Pengaturan ini dalam aplikasinya menimbulkan persoalan terkait perkembangan Bank Syariah kedepannya. Tidak diperkenankannya bank yang tidak berasaskan prinsip bagi hasil untuk melakukan usaha yang berasaskan prinsip bagi hasil atau sebaliknya, jelas berimplikasi terhadap lambatnya perkembangan Perbankan Syariah di tanah air. Hal ini disebabkan karena jalur pertumbuhan Bank Syariah hanya melalui pembukaan Bank Syariah yang baru.

Berhasilnya pendirian BMI sebagai bank yang menganut prinsip Syariah telah pula mengilhami kesadaran masyarakat untuk secara lebih dalam mengamalkan ekonomi Syariah. Sejalan dengan itu, berdirilah pula Bank Perkreditan Rakyat Syariah. Sebagai langkah awal yang lebih konkrit, lahir BPR Islam rintisan yaitu PT. BPR Dana Mardhatilla di Kecamatan Margahayu, PT. BPR Berkah Amal Sejahtera di Kecamatan Padalarang, kemudian PT. BPR Amanah Rabbaniah di Kecamatan Banjaran Kabupaten Bandung. Ketiga BPR ini akhirnya pada tanggal 8 Oktober 1990 telah mendapatkan izin prinsip Menteri Keuangan RI. Kemudian dilakukan persiapanpersiapan yang lebih intensif, terutama menyangkut sumber daya manusia sebagai pengelola bank yang lebih amanah, professional dan acceptable. Berkat bantuan tehnikal assisten penuh dari Bank Bukopin Cabang Bandung, yang memperlancar penyelenggaraan pelatihan dan bertemunya para pakar perbankan maka kemudian ketiga BPR Islam ini telah mendapatkan izin usaha dari Menteri Keuangan RI. 14

Demikian selanjutnya pendirian BPR Islam dan Bank Syariah telah menyebar ke berbagai wilayah di tanah air, sebagai respon dari keinginan masyarakat Islam yang ada di wilayah tersebut. Perkembangan ini juga tidak terlepas dari terjadinya penguatan dari regulasi yang ada. Misalnya setelah berlakunya Undang-Undang No. 7 Tahun 1992, pada Tahun 1998 telah disahkan Undang-Undang No. 10 Tahun 1998 tentang perubahan atas Undang-Undang No. 7 Tahun 1992 tentang Perbankan. Sehingga dalam tataran ini, pengaturan mengenai Perbankan Islam yang dulu hanya disebutkan sebagai "bank

\footnotetext{
14 Warkum Sumitro Op.Cit. hlm. 110.
}

berdasarkan prinsip bagi hasil", sekarang dalam undang-undang tersebut sudah dinyatakan secara jelas dengan menggunakan istilah "Bank Berdasarkan Prinsip Syariah". Sebagaimana dijelaskan dalam Pasal 1 Ayat (3) UndangUndang No. 10 Tahun 1998, antara lain menyatakan bahwa Bank Umum adalah bank yang melaksanakan kegiatan usaha secara konvensional dan/atau berdasarkan prinsip Syariah. Sedangkan Ayat (4) menyatakan bahwa Bank Perkreditan Rakyat adalah bank yang melaksanakan kegiatan secara konvensional atau berdasarkan prinsip Syariah. Prinsip Syariah yang dimaksud dalam undang-undang ini dijelaskan dalam Pasal 1 angka 13 yaitu adalah aturan perjanjian berdasarkan hukum Islam antara bank dengan pihak lain untuk penyimpanan dana dan atau pembiayaan kegiatan usaha, atau kegiatan lainnya yang dinyatakan sesuai dengan Syariah.

Kebolehan bagi bank-bank konvensional untuk membuka cabang Syariah atau merubah diri menjadi Bank Syariah dimaksud, tentu sangat mempengaruhi pertumbuhan dan perkembangan Bank Syariah ataupun BPRS. Ibarat cendawan di musim hujan tumbuh subur diseluruh tempat di tanah air. Namun demikian, para praktisi, para ahli perbankan Syariah serta para akademisi terkait tetap saja mengharapkan adanya undangundang yang secara khusus mengatur tentang Bank Syariah.

Harapan tersebut rupanya bak gayung bersambut, bermula setelah lahirnya UndangUndang No. 23 Tahun 1999 tentang Bank Indonesia, yang sekarang telah diubah dengan Undang-Undang No. 3 Tahun 2004, telah memuat beberapa ketentuan khusus berkaitan dengan keberadaan dan pengembangan Perbankan Syariah di tanah air. Dalam Pasal 10 Undang -Undang No 23 Tahun 1999 menyangkut persoalan pengendalian moneter, Bank Indonesia telah diberikan amanat untuk melaksanakannya berdasarkan Prinsip Syariah. Kemudian agar Bank Syariah dapat beroperasi secara optimal serta untuk melengkapi aturan hukum beroperasinya Bank Syariah maka lahirlah UndangUndang tentang Perbankan Syariah No 21 Tahun 2008 pada tanggal 16 Juli 2008.

Menurut Undang-Undang Perbankan Syariah agar dapat dikategorikan dalam lingkup ekonomi Syariah, maka ditentukan oleh fatwa MUI. Sehingga ada dua hal penting yang bisa dibutiri dari ketentuan ini, yakni terhadap ketentuan 
menyangkut Perbankan Syariah maka dalam aplikasinya fatwa dituangkan dalam peraturan Bank Indonesia. Ketentuan untuk transaksi ekonomi Syariah selain Perbankan Syariah, juga didasarkan pada fatwa MUI namun dalam aturan lanjutannya diatur oleh peraturan perundangan atau peraturan lainnya.

MUI sebagai lembaga yang memiliki kewenangan dalam bidang keagamaan serta berhubungan dengan kepentingan umat Islam Indonesia, membentuk Dewan Syariah Nasional (DSN). DSN diperuntukkan menangani masalahmasalah yang berhubungan dengan aktivitas Lembaga Keuangan Syariah (LKS). Sedangkan Dewan Pengawas Syariah (DPS) adalah badan yang ada di LKS dan bertugas mengawasi pelaksanaan keputusan DSN di LKS.

Pemikiran untuk dibentuknya DSN, sebenarnya diajukan pertama kali pada lokakarya Alim Ulama yang diselenggarakan pada tanggal 29-31 Juli 1997 di Jakarta. Alasan pembentukan DSN pada lokakarya tersebut, selain untuk membentuk lembaga yang dapat mengintegrasikan dan mengkoordinir setiap DPS yang terdapat disetiap LKS, juga untuk mengawasi seluruh kegiatan LKS, agar tidak menyimpang dari ketentuan Syariah. Selain itu pembentukan DSN diharapkan juga mampu menjawab berbagai permasalahan keuangan dan perekonomian dimana dalam operasionalisasi dan penyelesaiannya memerlukan keterlibatan hukum Syariah. ${ }^{15}$

Lembaga DSN MUI akhirnya resmi berdiri tanggal 10 Februari 1999 sesuai dengan Surat Keputusan (SK) MUI No. kep754/MUI/II/1999. Otoritas kuat yang dimiliki oleh lembaga ini adalah penentuan dan penjagaan menerapan Prinsip Syariah dalam operasional di LKS seperti perbankan Syariah, asuransi Syariah, reasuransi Syariah, reksadana Syariah, obligasi Syariah dan surat berharga Syariah, pembiayaan Syariah, sekuritas Syariah dan lain-lain. Hal ini disebabkan LKS ataupun kegiatan bisnis Syariah lainnya, memiliki karakteristik khusus yang berbeda dengan pengelolaan lembaga keuangan atau kegiatan bisnis konvensional.

Satu hal yang menarik dari menjamurnya kegiatan-kegiatan usaha dengan prinsip Syariah ini adalah menyangkut pola penyelesaian

15 Abdul Ghofur Anshori, Aspek Hukum Reksa Dana Syariah di Indonesia, (Bandung: Refika Aditama, 2008), hlm. 92. sengketanya terkait mengenai kewenangan Pengadilan Agama. Sebagaimana diatur dalam Undang-Undang No. 3 tahun 2006 tentang Perubahan Atas Undang-Undang No. 7 Tahun 1989 tentang Peradilan Agama Pasal 49 menentukan bahwa Pengadilan Agama berwenang memeriksa dan memutus sengketa tentang ekonomi Syariah.

Jika ditelusuri lebih jauh, kewenangan mutlak yang selama ini diemban oleh Peradilan Agama, sebenarnya secara sosiologis telah dipraktikkan oleh masyarakat. Artinya telah menjadi hukum yang hidup dan dipraktikkan masyarakat muslim yang ada di Indonesia. Berdasarkan fakta demikian, munculnya politik Hukum Ekonomi Syariah tentu tidaklah terlalu mengagetkan. Inilah mungkin yang dijadikan dasar oleh Dewan Perwakilan Rakyat mengesahkan kewenangan ekonomi Syariah dalam Undang-Undang No. 3 Tahun 2006, yang pertimbangan utamanya adalah “...bahwa Ekonomi Syariah adalah bidang perdata yang secara sosiologis merupakan kebutuhan umat Islam". Namun luasnya cakupan ekonomi Syariah tetap saja memerlukan perhatian tersendiri, jika dibandingkan dengan kewenangan lainnya dari Peradilan Agama.

Kondisi tersebut di atas tentu melahirkan beberapa harapan, salah satunya adalah kesiapan para hakimnya, baik terhadap kajian fikih Islamnya dan regulasi terkait, serta pemahaman terhadap produk-produk yang tersedia di Perbankan Syariah ataupun LKS dan juga terhadap pola-pola sengketa yang mungkin terjadi.

Mahkamah Agung RI dalam merealisasikan kewenangan baru Peradilan Agama tersebut telah menetapkan beberapa kebijakan ${ }^{16}$ antara lain : pertama, memperbaiki sarana dan prasarana lembaga lembaga Peradilan Agama baik hal yang menyangkut fisik gedung maupun hal-hal terkait peralatan. Kedua, meningkatkan kemampuan teknis sumber daya manusia (SDM) Peradilan Agama dengan mengadakan kerjasama dengan beberapa Perguruan Tinggi untuk mendidik para aparat Peradilan Agama, terutama para hakim dalam bidang ekonomi Syariah. Ketiga, membentuk hukum formil dan materil agar menjadi pedoman bagi aparat Peradilan Agama dalam

16 Penjelasan tentang ini ditemui dalam sejarah singkat penyusunan Kompilasi Hukum Ekonomi, Jakarta: Mahkamah Agung RI, 2008), hlm. x-xi. 
memeriksa, mengadili dan memutuskan perkara ekonomi Syariah. Keempat, membenahi sistem dan prosedur agar perkara yang menyangkut ekonomi Syariah dapat dilaksanakan secara sederhana, mudah dan biaya ringan.

Langkah-langkah konkrit dari bentuk meningkatkan teknis sumber daya manusia, sebagaimana upaya-upaya Tim E dan Pokja Agama Mahkamah Agung seperti pertama, mengikuti pelatihan di Sudan, Arab Saudi dan Negara Timur Tengah lainnya serta pelatihan sertifikasi hakim Pengadilan Agama. Kedua, mendorong para hakim Peradilan Agama untuk mempelajari putusan-putusan tentang sengketa ekonomi, baik Syariah atau Konvensional, dan baik putusan Pengadilan Agama ataupun Pengadilan Negeri. Ketiga, mempelajari cara penanganan dan pembuatan putusan tentang sengketa ekonomi Syariah dari hakim lingkungan Peradilan Umum, yang pernah menangani sengketa ekonomi Syariah. Keempat, mendorong hakim dilingkungan Peradilan Agama untuk mengikuti pendidikan S2 dan S3 bidang ekonomi. Kelima, melakukan telaahan terhadap buku-buku dan kitab-kitab yang berkaitan dengan ekonomi Syariah.

Pihak Bank Indonesia yang semula meragukan kemampuan hakim Pengadilan Agama, sudah bisa meyakini kemampuan aparat Peradilan Agama untuk menyelesaikan sengketa ekonomi Syariah. Pihak Bank Indonesia meminta agar sengketa ekonomi Syariah ditangani oleh hakim Pengadilan Agama yang sudah bersertifikat dan disetiap Pengadilan Agama minimal terdapat satu majelis hakim yang telah mendapat sertifikat untuk menangani sengketa ekonomi Syariah.

Menyahuti keinginan tersebut, Peradilan Agama mentargetkan sekitar kurang lebih 1300 orang hakim Peradilan Agama untuk mendapatkan sertifikat mengadili sengketa ekonomi Syariah. Sampai tahun 2012 sudah ada 280 orang hakim yang bersertifikat. Direncanakan pada tahun 2013 akan diusulkan 120 orang hakim Peradilan Agama untuk mengikuti pelatihan tersebut. ${ }^{17}$

Sedangkan kegiatan yang menyangkut hukum formil dan materil ekonomi Syariah, ketua Mahkamah Agung RI telah membentuk Tim

17 Fathurrohman Ghozalie, Laporan Pelatihan Sertifikasi Ekonomi Syariah, 2013
Penyusunan Kompilasi Hukum Ekonomi Syariah berdasarkan Surat Keputusan Nomor : KMA/097/SK/X/2006 tanggal 20 Oktober 2006. Hasil kerja Tim ini kemudian dilaporkan kepada Ketua Mahkamah Agung yaitu Bagir Manan untuk selanjutnya dibuatkan payung hukum untuk pelaksanaannya. Pada Tanggal 10 September 2008 ditetapkanlah Peraturan Mahkamah Agung RI No. 2 Tahun 2008 tentang Kompilasi Hukum Ekonomi Syariah (KHES). KHES terdiri dari empat buku yaitu Buku I tentang Subjek Hukum dan Amwal. Buku II tentang Akad. Buku III tentang Zakat dan Hibah. Buku IV tentang Akuntansi Syariah.

\section{Ruang Lingkup Kewenangan Peradilan Agama Dalam Mengadili Sengketa Ekonomi Syariah Melingkupi Semua Sengketa Ekonomi Syariah Bidang Hukum Perdata}

Sebagaimana diatur dalam Undang-Undang No. 3 tahun 2006 tentang Perubahan Atas Undang-Undang No. 7 Tahun 1989 tentang Peradilan Agama Pasal 49 menentukan bahwa Pengadilan Agama berwenang memeriksa dan memutus sengketa tentang ekonomi Syariah. Penjelasan Pasal 49 menyebutkan rincian bidangbidang yang termasuk dalam lingkup ekonomi Syariah adalah 11 bidang. Adapun yang dimaksud dengan Ekonomi Syari'ah adalah perbuatan atau kegiatan usaha yang dilaksanakan menurut prinsip syari'ah antara lain meliputi : bank syari'ah, lembaga keuangan mikro syari'ah, asuransi syari'ah, reasuransi syari'ah, reksa dana syari'ah, obligasi syari'ah dan surat berharga berjangka menengah syari'ah, sekuritas syari'ah, pembiayaan syari'ah, penggadaian syari'ah, dana pensiun lembaga keuangan syari'ah dan bisnis syari'ah.

Penyebutan 11 bidang tersebut di atas, tentulah tidak bersifat limitatif hal ini dikarenakan sebelumnya didahului oleh kata 'antara lain', sehingga tentunya tidak tertutup kemungkinan diluar 11 bidang dimaksud masih ada bidang kegiatan ekonomi Syariah lainnya yang masuk. Demikian misalnya masih terbuka pada bentuk kegiatan usaha seperti perusahaan Syariah, kepailitan Syariah, persaingan usaha Syariah, dan lain sebagainya. Walaupun menurut Abdurrahman (Hakim pada Mahkamah Agung Republik Indonesia), hal- hal tersebut dalam kaitannya dengan kewenangan Peradilan Agama 
masih terdapat perbedaan pendapat. ${ }^{18}$ Perbedaan pendapat menyangkut bidang yang belum disebutkan dalam 11 bidang dimaksud tentu selalu saja menimbulkan pertanyaan apakah Pengadilan Agama berwenang untuk memeriksa dan mengadilinya atau tidak. Tetapi berangkat dari Penjelasan Pasal 49 tersebut di atas, yang tidak memberikan pengecualiaan maka lingkup kewenangan Peradilan Agama bidang ekonomi Syariah adalah meliputi seluruh perbuatan atau kegiatan usaha yang dilaksanakan menurut prinsip Syariah. Dalam rancangan semula kewenangan ini hanya terbatas pada persoalan Perbankan Syariah, tetapi kemudian ditambah menjadi ekonomi Syariah. Karenanya, dalam Penjelasan Pasal 49 tersebut dikatakan bahwa penyelesaian sengketa tidak hanya dibatasi di bidang Perbankan Syariah melainkan juga di bidang ekonomi Syariah lainnya.

Pengertian tentang Prinsip Syariah mengalami perubahan dalam Undang-Undang No. 21 Tahun 2008 tentang Perbankan Syariah, sebagaimana dirumuskan dalam Pasal 1 angka 12 bahwa "Prinsip Syariah adalah prinsip hukum Islam dalam kegiatan perbankan berdasarkan fatwa yang dikeluarkan oleh lembaga yang memiliki kewenangan dalam penetapan fatwa di bidang Syariah". Disamping itu Perbankan Syariah dalam melakukan kegiatan usahanya disamping berasaskan Prinsip Syariah juga berasaskan kepada demokrasi ekonomi dan prinsip kehati-hatian. Hal ini tertera dalam Pasal 2 dan dalam Penjelasannya menyebutkan bahwa kegiatan usaha yang berasaskan prinsip Syariah, antara lain adalah kegiatan usaha yang tidak mengandung unsur :

a. Riba, yaitu penambahan pendapatan secara tidak sah (batil) antara lain dalam transaksi pertukaran barang sejenis yang tidak sama kualitas, kuantitas, dan waktu penyerahan (fadb) atau dalam transaksi pinjammeminjam yang memberikan syarat kepada Nasabah Penerima Fasilitas mengembalikan dana yang diterima melebihi pokok pinjaman karena berjalannya waktu (nasi'ab);

b. Maisir, yaitu transaksi yang digantungkan kepada suatu keadaan yang tidak pasti dan bersifat untung-untungan;

c. Gharar, yaitu transaksi yang objeknya tidak jelas, tidak dimiliki, tidak diketahui keberadaanya, atau tidak dapat diserahkan pada saat transaksi dilakukan kecuali diatur lain dalam syariah;

d. Haram, yaitu transaksi yang objeknya dilarang dalam syariah; atau

e. Zalim, yaitu transaksi yang menimbulkan ketidakadilan bagi pihak lainnya. Yang dimaksud 'demokrasi ekonomi' adalah kegiatan ekonomi syariah yang mengandung nilai keadilan, kebersamaan, pemerataan, dan kemanfaatan. Yang dimaksud dengan 'prinsip kehati-hatian' adalah pedoman pengelolaan Bank yang wajib dianut guna mewujudkan perbankan yang sehat, kuat, dan efisien sesuai dengan ketentuan peraturan perundang-undangan.

Lebih lanjut Pasal 26 menegaskan bahwa :

(1) Kegiatan usaha sebagaimana dimaksud dalam Pasal 19, Pasal 20 dan Pasal 21 dan/atau produk dan jasa syariah, wajib tunduk kepada Prinsip Syariah.

(2) Prinsip Syariah sebagaimana dimaksud pada ayat (1) difatwakan oleh Majelis Ulama Indonesia.

(3) Fatwa sebagaimana dimaksud pada ayat (2) dituangkan dalam Peraturan Bank Indonesia.

(4) Dalam rangka penyusunan Peraturan Bank Indonesia sebagaimana dimaksud pada ayat (3), Bank Indonesia membentuk komite Perbankan Syariah.

(5) Ketentuan lebih lanjut mengenai tata cara pembentukan, keanggotaan, dan tugas Komite Perbankan Syariah sebagaimana dimaksud pada ayat (4) diatur dengan Peraturan Bank Indonesia.

Penegasan Prinsip Syariah sebagaimana di atas, tentu tidak hanya dapat diberlakukan pada kegiatan usaha terkait Perbankan Syariah, tetapi juga dapat diimplementasikan pada berbagai transaksi ekonomi Syariah di luar Perbankan Syariah, asalkan transaksi ekonomi tersebut masuk dalam lingkup ekonomi Syariah.

Bertitik tolak dari penjelasan di atas, maka semua perkara atau sengketa ekonomi Syariah di bidang perdata merupakan kewenangan mutlak lingkungan Peradilan Agama untuk menerima, memeriksa, memutus dan menyelesaikannya, kecuali kalau secara tegas ditentukan lain oleh peraturan perundang-undangan.

18 Abdurrahman, Op.Cit.hlm. 8 
Melingkupi Sengketa Ekonomi Syariah yang Tidak Hanya Terjadi antara OrangOrang yang Beragama Islam Melainkan juga dengan Non Islam

Pasal 49 Undang-Undang No. 3 tahun 2006 menyatakan bahwa "Pengadilan Agama bertugas dan berwenang memeriksa, memutus, dan menyelesaikan perkara-perkara di tingkat pertama antara orang-orang yang beragama Islam di bidang perkawinan, waris, wasiat, hibah, wakaf, zakat, infaq, shadaqah; dan ekonomi syari'ah". Kemudian dalam Penjelasan Pasal 49 diuraikan lebih lanjut bahwa yang dimaksud "antara orang yang beragama Islam" adalah termasuk orang atau badan hukum yang dengan sendirinya menundukan diri dengan sukarela kepada hukum Islam mengenai hal-hal yang menjadi kewenangan Peradilan Agama sesuai dengan ketentuan Pasal ini.

Berangkat dari ketentuan ini subyek hukum ${ }^{19}$ yang dapat berperkara di lingkungan Peradilan Agama adalah : Pertama, orang yang beragama Islam. Kedua, orang yang beragama non Islam namun dengan sendirinya menundukkan diri dengan sukarela kepada Hukum Islam. Ketiga, Badan Hukum yang melakukan kegiatan usaha berdasarkan Hukum Islam.

Dengan demikian subyek hukum yang non Islam dimungkinkan sebagai pihak dalam perkara ekonomi Syariah di Peradilan Agama termasuk Badan Hukum. Asas penting yang baru diberlakukan dalam ketentuan ini adalah asas penundukan diri. Penundukkan diri pada Hukum Islam bisa dilakukan baik karena keinginan yang bersangkutan menghendaki atau karena hukum itu sendiri menghendaki demikian. Jika dikaji isi Penjelasan Pasal tersebut di atas, terdapat kata "sukarela" sedangkan kata sebelumnya "dengan sendirinya" sehingga yang dimaksud dengan penundukan diri dalam Penjelasan Pasal tersebut bukan penundukan diri secara sukarela tetapi memang hukum sendiri

19 Subyek hukum yang dimaksud disini adalah segala sesuatu yang menurut hukum dapat mempunyai hak dan kewajiban termasuk Badan Hukum. Yang dimaksud dengan manusia secara yuridis adalah orang (persoon) yang dalam hukum mempunyai hak subyektif dan kewenangan hukum. Sedangkan Badan Hukum adalah badan yang dapat mempunyai harta kekayaan, hak serta kewajiban seperti orang pribadi...lebih lanjut lihat dalam Hairuman Pasaribu dan Suhrawardi K Lubis, Hukum Perjanjian dalam Islam (Jakarta : Sinar Grafika, 1996), hlm. 14. menghendaki demikian. Sehingga sengketa ekonomi Syariah yang melibatkan subyek hukum non Islam maka yang bersangkutan harus tunduk kepada Hukum Islam karena undangundang menghendaki dengan sendirinya menundukkan diri kepada Hukum Islam

Ketentuan ini telah merubah paradigma lama bahwa subyek hukumnya hanya terbatas bagi orang-orang yang Islam saja. Hal ini terutama sebagai respon atas perkembangan hukum dan kebutuhan hukum masyarakat serta mengakomodir fakta bahwa banyak pelaku ekonomi Syariah bukan hanya orang Islam tapi juga non Islam.

Terkait uraian di atas, Undang-Undang No. 50 Tahun 2009 tentang Perubahan Kedua Undang-Undang No. 7 Tahun 1989 tentang Peradilan Agama pada Pasal 1 Angka 1 menegaskan bahwa " Peradilan Agama adalah peradilan bagi orang-orang yang beragama Islam". Jika dipahami ketentuan Pasal dalam Undang-Undang ini tanpa mengkaji perubahan Undang-Undang sebelumnya maka hanya orangorang yang beragama Islam saja yang bisa berperkara di Pengadilan Agama. Namun jika ditelusuri lebih jauh tidak ada ketentuan dalam Undang-Undang No. 50 Tahun 2009 yang menggantikan atau merubah Pasal 49 UndangUndang No. 3 Tahun 2006 serta Penjelasannya.

Bercermin pada Pasal 106 A yang menggariskan bahwa pada saat Undang-Undang No. 3 Tahun 2006 mulai berlaku, maka UndangUndang No. 7 Tahun 1989 masih tetap berlaku sepanjang tidak bertentangan dan belum diganti oleh Undang-Undang No. 3 Tahun 2006. Dengan demikian aturan ini juga bisa diterapkan terhadap Undang-Undang No. 50 Tahun 2009 bahwa Pasal 49 dan Penjelasannya yang terdapat pada Undang-Undang N0. 3 Tahun 2006, masih tetap berlaku karena belum diganti atau diubah oleh Undang-Undang No. 50 Tahun 2009.

Tidak Melingkupi Klausul yang Memperjanjikan Penyelesaian Sengketa Selain Peradilan Agama (Sesuai Isi Akad)

Undang-Undang No. 21 Tahun 2008 tentang Perbankan Syariah Pasal 55 menjelaskan bahwa:

(1) Penyelesaian sengketa Perbankan Syariah dilakukan oleh pengadilan dalam lingkungan Peradilan Agama.

(2) Dalam hal para pihak telah memperjanjikan penyelesaian sengketa selain sebagaimana 
dimaksud pada ayat (1), penyelesaian sengketa sesuai dengan isi akad.

(3) Penyelesaian sengketa sebagaimana dimaksud pada ayat (2) tidak boleh bertentangan dengan Prinsip Syariah.

Ketentuan tersebut di atas memberikan penegasan bahwa penyelesaian sengketa Perbankan Syariah adalah kewenangan absolut pengadilan dalam Lingkungan Peradilan Agama. Namun jika para pihak telah memperjanjikan penyelesaian sengketa selain ke Pengadilan Agama maksudnya dengan cara non litigasi, maka penyelesaian sengketa dilakukan sesuai dengan isi akad. Dengan demikian gugur kewenangan Pengadilan Agama untuk menyelesaikan sengketa tersebut. Sesuai dengan isi akad dimaksud sebagaimana disebutkan dalam penjelasan Pasal 55 Ayat (2) bisa melalui proses litigasi ke pengadilan dalam lingkungan Peradilan Umum atau upaya musyawarah, mediasi perbankan serta melalui Badan Arbitrase Syariah Nasional (BASYARNAS) atau badan arbitrase lain. Ketentuan dalam Penjelasan Pasal 55 Ayat (2) ini oleh amar putusan Mahkamah Konstitusi yang diucapkan dalam sidang Pleno Mahkamah Konstitusi terbuka untuk umum pada Kamis tanggal 29 Agustus 2013, dianggap bertentangan dengan UUD 1945 dan tidak mempunyai kekuatan hukum mengikat, karena mengandung ketidakpastian hukum bagi pihak pencari keadilan.

\section{Tidak Melingkupi Hal-hal Terkait Putusan Arbitrase Syariah}

Berdasarkan Pasal 59 Ayat (3) UndangUndang No. 48 Tahun 2009 tentang Kekuasaan Kehakiman dan Penjelasannya menentukan bahwa dalam hal para pihak tidak melaksanakan putusan arbitrase (termasuk Arbitrase Syariah) secara sukarela, putusan dilaksanakan berdasarkan perintah Ketua Pengadilan Negeri atas permohonan salah satu pihak yang bersengketa.

Sehubungan dengan ketentuan tersebut di atas, lahirlah Surat Edaran Mahkamah Agung (SEMA) No. 08 Tahun 2010 tentang Penegasan tidak Berlakunya SEMA No. 08 tahun 2008 tentang Eksekusi Putusan Badan Arbitrase Syariah yang isinya mengadopsi Pasal 59 Ayat (3) Undang-Undang No. 48 Tahun 2009, sebagaimana telah disebutkan di atas.

Sejak terbitnya SEMA No. 08 Tahun 2010 ketentuan dalam SEMA No. 08 Tahun 2008 yakni bahwa Ketua Pengadilan Agama berwenang memerintahkan pelaksanaan putusan Badan Arbitrase Syariah dinyatakan tidak berlaku.

Jelasnya hal-hal yang menyangkut putusan Arbitrase Syariah yang bukan lagi kewenangan absolut Peradilan Agama yakni menyangkut : Pertama, penyerahanan dan pendaftaran putusan Arbitrase Syariah. Kedua, pendaftaran permohonan eksekusi dan pelaksanaan eksekusi. Ketiga, permohonan pembatalan putusan Arbitrase dan pemeriksaannya, dalam hal apabila putusan tersebut diduga mengandung unsurunsur tertentu sebagaimana diatur lebih lanjut dalam Pasal 70 Undang-Undang No. 30 Tahun 1999 tentang Arbitrase dan APS.

Demikianlah hal-hal yang harus diperhatikan ketika membahas persoalan ruang lingkup kewenangan Peradilan Agama dalam mengadili sengketa ekonomi Syariah, meskipun berdasarkan Undang-Undang No. 3 Tahun 2006 Peradilan Agama memiliki kompetensi absolut menangani perkara ekonomi Syariah termasuk juga di dalamnya sengketa Perbankan Syariah. Lahirnya Undang-Undang No. 21 Tahun 2008, Undang-Undang No. 48 tahun 2009 serta SEMA No. 08 Tahun 2010 kewenangan dalam bidang dimaksud mengalami reduksi.

Penyelesaian sengketa ekonomi Syariah dalam lingkup litigasi diwenangi secara mutlak hanya oleh lembaga Peradilan Agama, sebagaimana isi amar putusan Mahkamah Konstitusi. Hal ini dianggap sangat tepat, sebab akan ditemui keselarasan antara impelementasi hukum materil yang berlandaskan prinsip-prinsip Syariah dengan lembaga Peradilan Agama yang memang merupakan wadah bagi para pencari keadilan yang beragama Islam atau mereka yang tunduk pada Hukum Islam, dapat terlaksana dengan baik. Keraguan terhadap kemampuan Peradilan Agama dalam menangani sengketa ekonomi Syariah dan Perbankan Syariah bukanlah alasan yang logis, karena Peradilan Agama telah didukung oleh seperangkat aturan yang bersifat khusus serta aparat yang beragama Islam dan memiliki kemampuan memahami Hukum Islam dengan baik.

\section{Penutup}

Ekonomi Syariah adalah bidang perdata yang secara sosiologis merupakan kebutuhan umat Islam, sebab itu kemudian Undang-Undang No. 
3 Tahun 2006 mengamanatkan sengketa ekonomi Syariah masuk dalam lingkup kewenangan Peradilan Agama. Namun peraturan perundang-undangan yang lahir belakangan telah mereduksi kewenangan dimaksud, meskipun telah lahir putusan MK yang mengembalikan sebagian kewenangan dimaksud, namun belum dibarengi dengan perubahan peraturan perundang-undangan lainnya. Setidaknya ada beberapa hal yang harus diperhatikan dalam menentukan batas ruang lingkup kewenangan Peradilan Agama dalam mengadili sengketa ekonomi Syariah. Pertama, melingkupi semua sengketa ekonomi Syariah bidang Hukum Perdata. Kedua, melingkupi sengketa ekonomi Syariah yang tidak hanya terjadi antara orangorang yang beragama Islam melainkan juga dengan non Islam. Ketiga, tidak melingkupi klausul yang memperjanjikan penyelesaian sengketa selain Peradilan Agama (sesuai isi akad). Keempat, tidak melingkupi hal-hal terkait putusan arbitrase Syariah.

Sejatinya memang penyelesaian sengketa ekonomi Syariah dalam lingkup litigasi diwenangi secara mutlak hanya oleh lembaga Peradilan Agama. Dengan pertimbangan bahwa akan ditemui keselarasan antara implementasi hukum materil yang berlandaskan prinsip-prinsip Syariah dengan lembaga Peradilan Agama yang memang merupakan wadah bagi para aparat yang Beragama Islam, pencari keadilan yang beragama Islam atau mereka yang tunduk pada Hukum Islam. Sehingga putusan yang dikeluarkan oleh Peradilan Agama adalah putusan yang benar-benar bertali ke langit dan berakar ke bawah (masyarakat).

\section{Daftar Rujukan}

Abdurrahman, Penyelesaian Sengketa Ekonomi Syariah di Indonesia, Makalah Orasi Ilmiah disampaikan pada Pembukaan Kuliah Fakultas Syariah IAIN Antasari, Banjarmasin, 30 Agustus 2010.
Ali, Muhammad Daud, Sistem Ekonomi Islam, Zakat dan Wakaf, Universitas Indonesia Press, Jakarta, 1988.

Anshori, Abdul Ghofur, Aspek Hukum Reksa Dana Syariah di Indonesia, Refika Aditama, Bandung, 2008.

Bisri, Cik Hasan, Peradilan Agama Di Indonesia, Raja Grapindo Persada, Jakarta, 1996.

Ghozalie, Fathurrohman, Laporan Pelatiban Sertifikasi Ekonomi Syariah, 2013

Halim, Abdul, Peradilan Agama dalam Politik Hukum di Indonesia. Dari Otoriter Konservatif Menuju Konfigurasi Demokratis-Responsif, RajaGrafindo Persada, Jakarta, 2000.

Lubis, Hairuman Pasaribu dan Suhrawardi K, Hukum Perjanjian dalam Islam, Sinar Grafika, Jakarta, 1996.

Noeh, Zaini Ahmad, (Trans). Daniel S. Lev, Peradilan Agama di Indonesia, Intermasa, Jakarta, 1980.

Sumitro, Warkum, Asas-Asas Perbankan Islam dan Lembaga-Lembaga terkait

( BAMUI dan Takaful) di Indonesia, RajaGrafindo Persada, Jakarta, 1997.

Undang-Undang RI No. 7 Tahun 1989 Tentang Peradilan Agama. Undang-Undang RI No. 3 Tahun 2006 tentang Perubahan atas Undang-Undang RI No. 7 Tahun 1989 tentang Peradilan Agama. Undang-Undang RI No. 50 Tahun 2009 tentang Perubahan Kedua atas Undang-Undang RI No. 7 Tahun 1989 tentang Peradilan Agama.

Undang-Undang RI No. 21 Tahun 2008 tentang Perbankan Syariah

Undang-Undang RI No. 48 Tahun 2009 tentang Kekuasaan Kehakiman.

Surat Edaran Mahkamah Agung (SEMA) No. 08 Tahun 2010 tentang Penegasan tidak Berlakunya SEMA No. 08 tahun 2008 tentang Eksekusi Putusan Badan Arbitrase Syariah. 